\title{
Reflections on the Pedagogy of My Professor and Mentor Katie Geneva Cannon
}

\author{
Edwin David Aponte \\ Louisville Institute
}

\begin{abstract}
This is a short reflection on aspects of the pedagogy and mentoring practice of Dr. Katie Geneva Cannon. This approach invited collaborative engagement and included a threefold process that included affirmation, inspiration, and charge. See companion contributions to this Forum written by Miguel A. De La Torre, Stacey M. Floyd-Thomas, Karen K. Seat, and Angela D. Sims.
\end{abstract}

\begin{abstract}
KEYWORDS
colleague, feasibility study, graduate work, mentor, mentorship, pedagogy, scholar, scholarly accompaniment, "seeing," teacher
\end{abstract}

She saved me from dropping out and showed me how to be a better scholar, teacher, and mentor.

I was starting my third year of doctoral studies in the department of religion at Temple University in Philadelphia. I was one of those doctoral students who did not take a straight path from undergraduate studies to the PhD. After receiving my first master's degree, I taught part-time at a small college while also working full-time at other jobs to pay the bills. Eventually I became a university financial aid administrator while continuing to teach as an adjunct. It was only after several years of being a university administrator and a contingent faculty person that I went on to study for the PhD in religion and culture.

That first year of doctoral studies at Temple University was challenging and surprising, starting with the university faculty going on strike. In that first year I also wrote a grant proposal to the Pew Charitable Trusts for a study of Latino/a Protestants in Philadelphia. The summer between the first and second years included an extended stay in Puerto Rico with the primary goal of enhancing my abilities in Spanish. My second year meant jumping into field work and seemingly innumerable trips of seventy miles each way from my home in the Lehigh Valley to Philadelphia. In addition to the field research in Philadelphia and the surrounding towns, I took a full load of graduate courses at Temple University, plus extra study to fill in my gaps in history, philosophy, feminist studies, political theory, postmodernity, postcolonial theory, sociology, anthropology, Hispanic/ Latino theologies, as well as various types of liberation theologies. In short order I needed to become familiar with the work and theories of Max Weber, Émile Durkheim, Michel Foucault, Karl Marx, Niebuhr (both Reinhold and H. Richard), Natalie Zemon Davis, Hayden White, Edward Said, Catherine Albanese, Jürgen Habermas, Clifford Geertz, Karen McCarthy Brown, Pierre Bourdieu, Gayatri Chakravorty Spivak, and many more. Given the inter-religious emphasis of the department, I studied African diaspora religions, Buddhism, and Islam, in addition to studies in my area of concentration. As I moved further into my studies I was deeply impressed and bit awed with the abilities of many of my colleagues in the program. Furthermore, beyond all the graduate work, I taught at regional colleges, not only for the teaching experience, but frankly because my family needed 
the money. I was worn out and stretched thin. I wondered if I could do this doctoral work, or if perhaps I should face facts and just quietly drop out and fade away. And at that critical juncture of extreme fatigue, growing doubt, and deepening despair, Dr. Katie Geneva Cannon arrived at Temple University and entered my life.

I enrolled for individual study with Dr. Cannon in a course called "Readings in African American Religion." What she laid out for me was enormously challenging, with of course lots of reading and writing, but even more than what I had been given in the two prior years for other courses. Dr. Cannon structured this course with multiple readings that included Souls of Black Folk by W. E. B. DuBois (2010), Albert J. Raboteau's Slave Religion (2004), Sisters in the Wilderness by Delores Williams (2013), and Cornel West's The American Evasion of Philosophy (1989). In retrospect I can recognize that part of Dr. Cannon's pedagogical approach was to introduce me to a canon of work in African American religious studies, but also both to invite me into critical conversations about the same, as well as to connect me with wider intellectual discussions. Moreover, Dr. Cannon's pedagogy for this reading course was unlike other "independent" studies that I had experienced where I had been left mostly on my own. This time it was different. Through reflection papers (not traditional book reviews) on each work and regular meetings I experienced engaged scholarly accompaniment. These one-to-one meetings were both critical conversations and tutorial, not only on the subject matter at hand, but also on how to be a scholarly mentor and colleague.

It was clear that something different was happening from the first time we met to discuss what I wrote as a reflection on a text. As we sat in her faculty office Dr. Cannon started by looking directly at me and saying, "You are brilliant." I was shocked, initially speechless, but also deeply moved. I am still moved today. I share this not to boast; certainly there are those who can give their own assessment of my intelligence and scholarly aptitude. I share this story because up until that moment no one had ever said that about me to me. At an extremely low point when I seriously contemplated slinking away and becoming another casualty of the higher education industrial complex, Dr. Cannon saw me in the fullest sense of the word. In that first meeting and in our subsequent meetings she affirmed me as a person and as a scholar, and in doing so she saved me from dropping out of the PhD program. She acknowledged my being, my scholarship, and my multifaceted calling. Part of Dr. Cannon's pedagogy was that she fully saw her students for who they were and could be, and boldly affirmed her students as critical thinkers and scholars who would engage the world.

By studying with Dr. Cannon new areas of discourse were opened up to me: Womanist theology, the writings of Delores Williams, James Cone, W. E. B. DuBois, Cornel West, Cheryl J. Sanders, Albert Raboteau, C. Eric Lincoln, Lawrence H. Mamiya, Gayraud Wilmore, Benjamin E. Mays, Emilie Townes, as well as many others. I took Dr. Cannon's seminar "Social Teachings in African American Sacred Rhetoric," where again I witnessed her passion for teaching and engaging complex subjects in ways that were contagious and invitational. She motivated me to be a zealous co-learner; I was also challenged and stimulated by her methodology of analysis. That methodology included writing weekly “Demystifying Domination Reflection Papers" designed to help us identify the ideology, theology, or the value system of the work we were reading, construct a cognitive map of the logic of the particular work, name the communities connected to the writer's claims of accountability, and unmask the sacred rhetoric present and how the moral values of the writer as activist interacted with their articulated social conscience. Moreover, Dr. Cannon's consistent, determined examination of African American sacred rhetoric identified a way for me in my exploration of Latino/a sacred rhetoric, including examining lo cotidiano (daily life), as well as other expressions of religious and spiritual discourse in various Latinx contexts. ${ }^{1}$

Another important part of Dr. Cannon's pedagogical approach to teaching a methodology of analysis was having us do a "Feasibility Study." Rather than assigning a typical research paper, Dr. Cannon provided us with a way to explore how to create a detailed intellectual blueprint that would be the basis for a thoughtful research paper. That is significant in itself, but all the more so because the assignment did not include writing the research paper. In the midst of the busyness of graduate school and life beyond the university, we were introduced to a disciplined way of doing what ought to have been implicit, but which, in the midst of our graduate student praxis, really had been a missing step. By having us focus on that missing step, the pedagogy employed was both exciting and counter-cultural. Dr. Cannon had us name a particular problem, hypothesis, or question that provided the focus of our individual desired research. The next step was to state a rationale for the desired study, to name significant prior research, and then to define any limitations and key assumptions - in essence doing an early stage self-critique, and finally outlining the methodology for data gathering and the process of analysis. The Feasibility Study approach is extremely useful and I incorporated it into my own pedagogy when it was my turn to teach. And I must confess that it was with pride, appreciation, and some hope that I told my students that I learned the Feasibility Study approach from Dr. Cannon, and that therefore they were part of an academic legacy that they would take with them into various callings of their own.

1 For example, readers might discern Dr. Cannon’s influence in my book ¡Santo! Varieties of Latino/a Spirituality (2012). 
In addition to learning from her and with her through individual study and in graduate seminars, Dr. Cannon agreed to serve on my dissertation committee and also as the reader for my doctoral examinations in "African American Religion and African Antecedents." In writing answers about the chief features of a West African worldview complex, continuities within African Diaspora communities, and their significance for study of the African Diaspora in the Western Hemisphere; or on how the central themes in The Souls of Black Folk (2010) address the fundamental aspects of African American social, political, and religious life; or reflecting on Albert Raboteau's understanding of the "invisible institution" in the antebellum South; or on bringing into conversation the rhetorical and philosophical approaches of W. E. B. DuBois and Benjamin E. Mays, and how each foreshadowed the prophetic pragmatism of Cornel West, I was motivated to do my best. Certainly I wanted to do well in the PhD exams, but at that point I also strove to excel because as a professor and scholar Dr. Cannon had put her faith in me, she had invested in me, and as her student I wanted to make her proud. Part of Dr. Cannon's pedagogy was that through respectful, invitational interactions she inspired her students to do their very best, not just for her, but also for themselves and their communities of accountability.

Years afterward, with both the PhD and a university tenure-track appointment in hand, one of the yearly joys of life was seeing Dr. Cannon each November for the annual meeting of the American Academy of Religion. One year, while walking with two Temple University colleagues who were also her students, we met Dr. Cannon in passing, to our great mutual delight. She paused to greet us effusively, then put her arms around us, drew us close, and looking into each of our faces she said, "Take care of each other." On that day and every day since, I have received what Dr. Cannon said not simply as good manners or kind advice, but also as encouragement, and ultimately as a solemn charge and challenge. I try to live up to that charge to be a good, supportive, and encouraging colleague to others, working collaboratively, avoiding competition, or any of the destructive behavior that is far too common in academia. Part of Dr. Cannon's pedagogy continued beyond our studies as she continued to mentor her students by charging us to care for each other.

I was blessed to study with Dr. Cannon at Temple University, she saved me from dropping out, and she served on my dissertation committee. Another gift she gave was that she placed the doctoral hood on my shoulders like a mantle at graduation. And by doing so, she sent me to go and do the same as she did: to affirm, inspire, and charge. She continues to influence my work as a scholar, teacher, and mentor. Dr. Katie Geneva Cannon help me to recognize and do "the work that my soul must have" to be a better scholar, teacher, and mentor.

\section{BIBLIOGRAPHY}

Aponte, Edwin David. 2012. jSanto! Varieties of Latino/a Spirituality. Maryknoll, NY: Orbis.

Du Bois, W. E. B. 2010. The Souls of Black Folk. New York, NY: Knopf.

Raboteau, Albert J. 2004. Slave Religion: The “Invisible Institution” in the Antebellum South. Oxford, UK: Oxford University Press.

West, Cornel. 1989. The American Evasion of Philosophy: A Genealogy of Pragmatism. Madison, WI: The University of Wisconsin Press.

Williams, Delores S. 2013. Sisters in the Wilderness: The Challenge of Womanist God-Talk. Maryknoll, NY: Orbis Books.

\section{ADDITIONAL CONTRIBUTORS TO THIS FORUM HONORING DR. KATIE GENEVA CANNON}

De La Torre, Miguel A. 2020. “Personalizing Katie’s Canon.” The Wabash Center Journal on Teaching 1(1): 97-99. https://doi.org/10.31046/wabashjournal.v1i1.1587.

Floyd-Thomas, Stacey M. 2020. "Teaching the Canon and Cannon Formation as Incarnation and Conjure: Dr. Katie Geneva Cannon as Womanist Mentor and Muse." The Wabash Center Journal on Teaching 1(1): 87-91. https://doi.org/10.31046/ wabashjournal.v1i1.1585. 
Seat, Karen K. 2020. “Creating Our Better Selves: The Fruits of Katie Cannon’s Womanist Pedagogy.” The Wabash Center Journal on Teaching 1(1): 93-95. https://doi.org/10.31046/wabashjournal.v1i1.1586.

Sims, Angela D. 2020. “Deep Breaths and High Impact Aerobics: Reflecting on Teaching Writing in the Key of Katie Geneva Cannon.” The Wabash Center Journal on Teaching 1(1): 101-105. https://doi.org/10.31046/wabashjournal.v1i1.1588.

\section{ABOUT THE AUTHOR}

Edwin David Aponte (PhD, Temple University) is Executive Director of the Louisville Institute and Research Professor of Religion and Culture at Louisville Seminary 